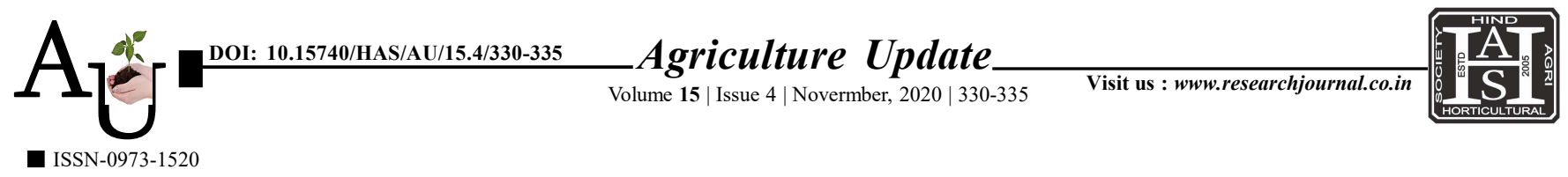

\title{
Research Article: Strategies for capacity building of agricultural extension personnel in using information and communication technologies for transfer of technology
}

\section{S. Helen and N. Mridula}

Article Chronicle : Received :

26.08.2020;

Revised:

28.09.2020;

Accepted :

16.10.2020

KeY Words :

Strategies, Capacity building of

agricultural extension, Personnel, ICTs

Author for correspondence :

\section{S. Helen}

Central Training

Institute, Kerala

Agricultural University,

Thrissur (Kerala) India

Email: helen.s@kau.in

See end of the article for

authors' affiliations Society.
SUMMARY : A study was conducted among 150 agricultural extension personnel from five districts of Kerala to identify the constraints faced by the agricultural extension personnel in using information and communication technologies (ICTs) in transfer of technology and suggested strategies for their capacity building. Lack of proper training facility was recorded as the most experienced constraint with a mean score value of 9.48 , followed by inadequate computer facility (8.82) available to them. The other major constraints experienced by the extension personnel were poor technical know how and conducting trainings at inappropriate times with a mean score of 8.32 each and lack of financial resources formain taining the ICT tools with the mean score of 8.03. It is suggested to categorise the extension personnel into two groups viz., those extension personnel who need the basics of ICTs and those extension personnel who require the knowledge on advanced ICTs. Target specific training modules, hands on experience, well established infrastructure, adequate funds and personnel for repair and maintenance, computer based trainings and advanced circulation of annual training calendars among extension personnel by the training organizations are the suggested strategies for the capacity building of extension personnel of Kerala in using ICTs.

How to cite this article : Helen, S. and Mridula, N. (2020). Strategies for capacity building of agricultural extension personnel in using information and communication technologies for transfer of technology. Agric. Update, 15(4): 330-335; DOI : 10.15740/HAS/AU/15.4/330-335. Copyright@ 2020: Hind Agri-Horticultural 